\title{
FLORISTIC DIVERSITY OF INDIA AN OVERVIEW
}

\section{SUNIT SINGH}

Research Scholar, Department of Botany and Microbiology, HNB central University, Uttarakhand, India

\begin{abstract}
This article spots light on the different biogeographic regions, their flora with some medicinal plants of those regions. Variegated geographical, altitudinal and climatic conditions of India makes it one of the richest biodiversity zones of the world. Plants of medicine, timber, avenue, fibre, phytochemicals etc.altogether make this possible.From sea shore to high mountains; from hot desert to cold desert; from region of higher rainfall to lower creates several habitats for different flora. In several countries the medicinal plants are used as remedies from ancient timetill today. As India is rich in floral diversity, traditional medicines and drugs are also used here from the ancient time. $50 \%$ plants of every biogeographic region of India are used as the ethnomedicine by the locals and few of them are also used by the scientists, doctors and practitioners.
\end{abstract}

KEYWORDS: Diversity, Biogeographic \& Medicinal Plants

Received: Sep 23, 2020; Accepted: Aug 13, 2020; Published: Nov 18, 2020; Paper Id.: IJBRDDEC20203

\section{INTRODUCTION}

'Floristic diversity' can be defined as the diversity of indigenous plants present in a specific area during a particular time period. India is known to have a vast diversity of flora due to various reasons; topological conditions, immense difference in climatic conditions and wide range of habitat favouring the life of different plants. About 4,65,688 species of plants have been known till today on the earth; among them 49,441 species are present in India including the bacteria, algae, lichen virus and fungi (1). India is one of the 17 megadiversity countries of the worldhaving $11.4 \%$ of the total known plant species of the whole world and $28 \%$ plant species are endemic (2). There is about $37.7 \%$ of Angiosperms, $0.15 \%$ of Gymnosperms, 5.27\% of Bryophyta, 2.66\% of Pteridophytes, $2.07 \%$ of Viruses, $15.24 \%$ of Algae, $31.05 \%$ of Fungi and $5.03 \%$ of Lichens of the total species found in India $(1,4)$. India is one of the tropical countries with 4 Phytogeographical regions viz., Himalayas, Western Ghats, North-east India(IndoBurma except Assam and Andaman Group of Islands) and Sundalands (Nicobar group of islands): also known as biodiversity hotspots of India out of the 34 biodiversity hotspots all over world.Biodiversity hotspots are those regions having 1500 endemic vascular plant species and also have lost $70 \%$ of the natural habitat. About $28 \%$ of Indian flora and about 33\% of angiosperms are endemic in India (26).Moreover, Physiographically India is divided into 6 regions - the Himalayas, the Indo-Gangetic planes, Peninsular region or the Deccan region, Indian Desert, Coastal Plains, Islands. India has 15,200km of land frontier, 329 million hectares of geographical area and 7500km long coastline with 10 biogeographical regions each with distinct vegetation depending on the type of climatic condition.

From ancient time plants are used for food, fodder, fuel and medicinal purpose. Among 49,441 plant species of India, 15000 are medicinal plants and 500 species of them are mostly used for the drugs (25). The whole plant material can be used as the medicine. Not only Ayurveda but Allopathy, Unani and Homeopathy also use 
plants for the drug production. Ayurveda has kept the ancient medicinal system alive till time. There are also several unexplored regions in India where many more medicinal plants can be found.

\section{ECOLOGICALDIVERSITY}

For the broad knowledge of the vegetation diversity of India, we have to understand the biogeography of India. For the better understanding, Rodgers and Panwar (1988) divided India into 10 biogeographical regions based on their distinct and unique vegetation. The vegetation diversity depends on the altitude, temperature, rainfall, salinity, topology etc. The vegetation is also categorized as: forest, Grasslands and shrubs etc. The climatic condition of India varies extremely from the coldest snowy Himalayan regions of North to the hottest region of Thar desert; least rainfall region to the highest rainfall region of the Northeast India; marine ecosystems to fresh water ecosystem and Mangroves of Sundarbans. The salinity of the soil decreases from the coastal regions to the mountain valleys with increasing altitude from the Sea level. The major factor for the extremity of the climatic change is the 'Asiatic monsoon' wind system which seasonally reverses its direction. The country has various habitats with fragile ecosystems like forest, wetlands, grasslands, coastal, desert(cold, hot) and marine which provide differential habitat for both flora and fauna causing major diversity. The geographic location of the country also gives hand making India one of the Megadiversity countries; as it is present at the convergence of 3 major biogeographical realms: Eurasian, Indo-Malaysian and Afro-tropical making the floristic diversity in India by intermingling the elements.

\section{BIOGEOGRAPHICAL DIVERSITY}

Biogeographical diversity shows the distribution of the species in a particular geographical region. India is one of the 17 megadiversity countries contributing $8 \%$ of the known biological species globally. Biogeographically India is divided into 10 zones with unique and distinct habitats and vegetation; based on biogeographic characteristics.

- Trans- Himalayan- Ladakh, Lahaulspiti.

- Himalayans- Jammu and Kashmir, Ladakh, Himachal Pradesh, Uttarakhand, Sikkim, Arunachal Pradesh, Nagaland, Manipur, Mizoram, Tripura, Meghalaya, Assam and West Bengal.

- North-east India- Arunachal Pradesh, Assam, Manipur, Meghalaya, Mizoram, Nagaland, Tripura and Sikkim.

- Indian Desert - Thar and Kutch.

- Western Ghats- Kerala, Tamil Nadu, Karnataka, Goa, Maharashtra and Gujarat.

- Semi-Arid regions- Punjab plains, Rajasthan, Haryana, Gujarat, Maharashtra.

- Deccan Peninsular- Telangana, Maharashtra, Andhra Pradesh, Karnataka, Kerala and Tamil Nadu.

- The Coastal zone- Kerala, Tamil Nadu, Karnataka, Andhra Pradesh, Gujarat, Goa, Maharashtra, Odisha, West Bengal, Lakshadweep.

- Indo- Gangetic planes- Gujarat, Sindh, Punjab, Bihar, Bengal and Assam.

- The Indian Islands- Andaman and Nicobar islands. 


\section{VEGETATIONAL DIVERSITY}

The 10 biogeographical regions show various and unique vegetation differing from each other which are mentioned below:

a. Trans Himalayan: These are present parallel to the Himalayas. Cold deserts, rocky regions and glaciers are the main components. The $1600 \mathrm{~km}$ long cold snowy mountain range is extended from north to east (3). Dry alpine scrubs are the major vegetation of this region; mainly Juniperus species.Thepresence of sparse vegetation; Carex, Draba, Ephedra, Kobresia, Saxifraga etc.is also seen.

Medicinal plants- The trans-Himalayan region has low species diversity and sparsely distributed vegetation. Ladakh region is well known for the maximum contribution of the geographical areas in this biogeographic zone along with Lahaul-spiti, Sikkim and Uttarakhand. Ephedra gerardiana, E.intermedia, Fritillaria roylei, Geranium sibricum, Meconopsis aculeata, Hippophae rhamnoides, Jurinea dolomiaea, Hyoscyamus niger, Juniperus communis, Podophyllum hexandrum, Saussurea gossypiphora, S.lappa, S.obvallata, Rheum webbianum, Bergenia stracheyi, Bunium persicum, Colchicum luteum etc.(27)

b. Himalayan: The Himalayan region is extended for about $2400 \mathrm{~km}$ from east to west and shows a vast vegetation of different floras; alpine, sub-alpines, temperate, sub-tropicalforest coincide here.25000 plant species are also found in Himalayas; representing about $10 \%$ of world's known and $50 \%$ of India's known endemic flora $(4,5)$. Temperature varies from $18-30^{\circ} \mathrm{C}$. This region is rich in temperate flora with extreme growth of grasses and evergreen tall trees like conifers and oaks in western Himalayas and broad leaf plants like rhododendrons and herb like orchids are mostly found in eastern Himalayas (5). Himalayas have a majority of plant species, someof them areJuniperus indica, Juniperus recurve, Juncus sikkimensis, Calamus inermis, Corydalis cashmeriana, Meconopsis simplicifolia, Berberis concinna, Aconitum spp., Saxifraga spp., Cotoneaster microphylla, Aconogonon hookeri, Rheum nobile, Cassiope fastigata, Goultheria trichophylla, Onosoma hookeri, Anaphalis hookeri, Nardostachys jatamansi, Anemone demissa, Caltha scapose, Atragalus zemuensis etc.

Medicinal plants- Himalayas are the store house of tons of medicinal plants with great economic and medicinal values. It is not only a beauty but also provides various information which are new to science and can be of great benefit to the society. The species of Rheum, Saussurea, Gentiana, Maconopsis, Cotoneaster, Polygonum, Anemone, Primula, Saxifraga, Allium, Cremanthodium, Corydalis, Juniperus, Ephedra, Hippophae, Aconitium, Podophyllum, Skimmia, Rhodiola, Ainsliaea, Dolomiaea, Dactylorhiza etc. are having great medicinal values. (24)

c. North-east Himalayan region: This region is most considerable among all biogeographical regions as it is rich in biological diversity and also a rich reservoir for variety of medicinal plants which are used for both medicinal and ethnomedicinal use; it is a transitional zone of different biogeographical regions of India, Indo-Chinese, Indo- Malayan causing the intermingling of various floral elements forming a gateway of plant migration. Its vegetation is rich and diverse being classified into tropical, subtropical and temperate regions. Around 17500 flowering plants are found in India, among which about $50 \%$ is found in this region (3) along with maximum numbers of primitive flowering plantsmotivated Takhtajan (in 1969) naming this region as 'Cradle of flowering plant'. Maximum endemism is also seen here (26). More than 80 spp.types of Rhododendrons and several species of Orchids (nearly 730 spp.), bamboo (65 spp.), ferns and other plants are mostly present here. The most primitive living angiosperm, Magnolia pterocarpa is also found here. Some plants present inthe North-eastern forest are Alpinia nigra, Begonia picta, Cardamine hirsuta, Chenopodium album, Amaranthus viridis, Curucoma angustifolia, Diplazium esculentum, Hedchium coronarium, Impatiens annulifera, Litsea citrate, Musa 
sapientum, Oroxylum indicum, Paederia foetida, Pogostemon elsholtzoides, Rhus semialata, Smilex ovalifolia, Trichodesma nudiflora, Viola distans, Castanopsis hystrix etc.

Medicinal plants- Being the richest reservoir of plant diversity, this region has also several medicinal plants like Oroxylum indicum, Smilax glabra, Paris polyphylla, Berginia cilate, Podophyllum hexandrum, Illicium griffithii, Coptis teeta, Swertia chiryata, Aconitum ferox, Aconitum heterophyllum, Vanda coerulea, Renanthera imschootiana, Rauvolfia serpentine, Aquilaria mallaccensis, Hibiscus Manihot, Abies spectabilis, Acorus calmus, Abutilon indicum, Abroma augusta etc.(30).

d. INDIAN DESERT: Indian desert includes the cold mountain desert of theTrans-Himalayas, the White Salt desert of Kutch and The Sandy desert of Rajasthan. Here we will discuss about the Sandy desert; Thar and salt desert; Kutch.

Thar desert is known as the Great Indian Desert which is present in the north-western part of India. It is a large arid region covers an area of about $200,000 \mathrm{~km}$ sq. It is the world's $17^{\text {th }}$ largest desert and the $9^{\text {th }}$ largest subtropical desert situated in Rajasthan (29). Its climate,especially, is very cold winter with about $5-10^{\circ} \mathrm{C}$ and dry and hot summer with temperature varying from $43-49^{\circ} \mathrm{C}$. It is covered with sand and rock, so most of the vegetationis xerophytic thorny trees with reduced leaves- Cactus spp., Acacia sp.,Saccharum munja and Prosopis juliflora. The odd landscape of the Great desert only supports the hardy, drought resistant plant species to cope with the desert environmental and topological conditions of sandy soil, scarcity of water and very strong sunlight. These plants are having deep root system to absorb the groundwater, small or reduced leaves with spiky thorns to reduce transpiration (7). The soil supports different binding species such as Aerva tomentosa, Citrulus colocynthis, Crotolaria burhia \& Leptadenia pyrotechnica. Bushes like Capparis decidua, Calligonumpolygonoides and Ziziphus are also found here. Lesser number of Tree species like Acacia, Tecomella undulata are found. Typical grasses of this zone are Cenchrus sp., Lasiurus syndicus.

In the salt desert of Kutch is a zone with high temperature, little rainfall and is also affected by the salinity. Due to these conditions the salt marshes and mangroves are mostly found here. Poaceae is the main dominated family here followed by Papilionaceae family.Senna auriculate, Acacia nilotica, Calotropis procera, Caltropis gigantia, Phyllanthus fraternus, Datura metel, Bulbostylis barbata, Argemone maxicanaforms the vegetation of this zone.

Medicinal Plants- Though the desert has very harsh and hot climatic conditions still it is very rich in flora diversity compared to the other deserts; one quarter of the total plants of the Thar desert is used for the benefits of the society. The medicinal plants of the Indian hot desert are mostly used in its raw form. Some Medicinal plants include Glycyrrhiza glabra, Tinospora cordifolia, Plantago ovata, Asparagus racemosus, Cassia angustifolia, Withania somnifera, Achyranthes aspera, Barleria prionitis, Boerhaavia diffusa, Eclipta alba, Euphorbia caducifolia, Evolvulus alsinoides, Pergularia daemia, Sida cordifolia, Solanum surattense etc. $(14,15,20)$.

e. SEMI ARID ZONE: This forms the transition zone between the desert and the dense forest of Western Ghats. This zone is divided into different regions: one of them is the productive agricultural region of Punjab and Haryana; another part surrounds the desert of western Gujarat and Rajasthan; some parts are present behind the Western Ghats forming the rain shadow area (13). The major vegetation of this zone is dry deciduous forest, and tropical thorny forest ofAilanthus excelsa, Acacia spp., Anogeissus latifolia, Capparis decidua, Dichrostachys cinerea,Diospyros melanoxylon, Prosopis cineraria and Flacourtia spp. etc.Grasses and some bamboos are also present. 
Medicinal plants- As the soil of this region is not appropriate for the cultivation so it is mostly used for the plantation of medicinal and fuel trees. The forest of this zone has many medicinal herbs with great medicinal values which were not only used by the ancient people but is also used by the scientist and medicine personalstoday. There may be several plants with good phytochemical property which can be completely novel to the world. Bacopa monnieri, Calotropis gigantea, Cannabis sativa, Centella asiatica, Acorus calamus, Cassia fistula, Cardiospermum helicacabum, Bauhinia vahlii, Asparagus racemosus, Asparagus adsecendens, Cyperus rotundus, Datura metel, Justicia adhatoda, Eclipta alba, Ricinus communis, Piper betle, Phyllanthus fraternus, Rauwolfia serpentina etc. (21).

f. WESTERN GHATS: In floral diversity it is second richest biogeographic region followed by Himalayas. It represents one of the 36 biodiversity hotspots all over world and one of the four hotspots in India. It is outstretched from Kanyakumari to Tapi river. This zone is laden by evergreen forest including plant species of Claophyllum, Dipterocarpus, Hopea and Mesua(8). This forest is rich with more than 4000 species of higher plants which represents about $27 \%$ of India's flora (6). Anaimalai and Nilgiri hills have subtropical forest at an altitude of 1800mt. The moist deciduous forest bears very expensive timber species such as Dalbergia latifolia, Pterocarpus marsupium, terminalia crenulate, Tectona grandis etc. Hills of Western Ghats are known for their endemism bearing about more than 1800 endemic species (2, 4). Variegated climatic conditions and heterogeneous topography creates differentiated habitats which is responsible for the unique set of plant species. At higher altitudes species of Elaeocarpus, Meliosma, Machilus, Syzygium, and Wendlandia are common. Bamboos including Bambusa spp. and Oxytenanthera; palms; Orchids; Peppers; Aroids; Gingibers are also found at the wet places formed near streams. The silent valley, an uninterrupted area of Western Ghats rain forest and tropical evergreen forest,is one of the most ecologically diverse regions of the world with some rare species; diverse species of flora and fauna makes it a rich storehouse of biodiversity.

Medicinal plants- Western Ghats are rich in plant biodiversity with annuals to perennials representing various life forms from lower plants to higher plants. The medicinal plants of Western Ghats are very complex as it is a treasure house of many of them. Some of them are Anona squamosa, Buchanania lanzan, Aphanamixis polystachya, Rauvolfia serpentine, Gymnema sylvestre, Gloriosa superba, Phyllanthus neruri, Tridax procumbens, Leucas aspera, Dioscorea bulbifera, Rhicanthus nasuta, Momordica dioica, Mimosa pudica, Hibiscus angulosus, Calotropis gigantea, Parthenium hysterophorus, Saraca asoca, Gloriosa superba, Strycnos nux-vomica, Phyllanthus neruri, Semcarpus anacardium etc.(25, 29).

g. DECCAN PENINSULA: It is India's largest biogeographical region mostly covered by Tropical thorn forest; Tropical dry forest is present in northern, central and southern part of the plateau; eastern part of the plateau is covered by moist deciduous forest. It is surrounded by Eastern and Western Ghats. This zone is present in Madhya Pradesh, Maharashtra and Odisha covering India's large portion of forest. Semi-arid zone species like Anogeissus latifolia, Butea monosperma, Boswellia serrata, Tectona grandis etc. are commonly found here. An endemic species Hardwickiabinata of Caesalpiniaceae can be seen in patches at the drier part of the peninsula. Species like Adina cordifolia, Diospyros exsculpta, Chloroxylonswietenia etc. are commonly found in tropical moist deciduous forest. $(9,12)$

Medicinal plants- This zone is rich with various wildlife plants, medicinal plants and agricultural fields as it has unique different and vast geographic regions. Enlisting the medicinal plants of Deccan peninsula- Azadirachta indica, Centella asiatica, Celastrus paniculatus, Chlorophytum tuberosum, Chlorophytum arundinaceum, Curcuma pseudomontana, Cycas circinalis, Drosera burmanii, Gloriosa superba, Oroxylum indicum, Santalum album, Terminalia 
arjuna, T. chebula, Tinospora cordifolia, Vitex negundo, Withania somnifera, Bixa orellana, Entada pursaetha, Zanthoxylum alatum etc.(19).

h. INDO-GANGETIC: This is the most productive and fertile region of India as it is formed by the Alluvial soil deposition of Ganges and its tributaries. Nowadays cultivated plants are replacing its natural vegetation. Moist deciduous forest, Riparian forests, Dry thorny forest, Dry deciduous forest and grasslands are seen here (9). Plant species Shorea robusta, Adena cordifolia, Mallotus philippensis, Callicarpa macrophyla, Murraya koenigii, Mitragyna parviflora, Grewia asiatica, Zizyphus mauritiana, Carissa spinarum etc. are found in moist deciduous forest. Acacia catechu, Trewia nudiflora and Dalbergia sissoo are common in Riparian forest. Calotropis procera, Prosopis spicigera, Ziziphus xylocarpus, Z. mummularia, Z. mauritiana, Butea monosperma are common vegetation of Dry thorny forest. Acacia nilotica, Tinospora cordifolia, Dioscorea hispida, Bombax ceiba, Lagerstroemia parviflora,Prosopisspicigera are common in Dry deciduous forest (12).

Medicinal plants-Some medicinal plants of this region are as Acacia arabica, Holoptela integrifolia, Madhuca indica, Launaea procumbens, Phyllanthus amara, Rosa centifolica, Solanum surattense, Tephrosia purpurea, Tinospora crispa, Tribulus terrestris, Terminalia bellerica, T. chebula, Cassia angustifolia, Cassia occidentalis, Centella asiasatica, Crotolaria burhai, Eclipta alba etc.(18).

i. COASTAL ZONE: India has long extended coastal region of about 5,500km with mangroves as the natural vegetation of this zone (11); fertile lands are suitable for the cultivation of rice and coconut trees. It is a healthy zone of India formed by sandy beaches with marine angiosperms, mangrove plants and coral reef. Genera like Avicennia, Bruguiera, Ceriops, Rhizophora, Heretiera and Xylocarpusforms the mangrove forest found near brackish water, deltas and estuaries.

Medicinal plants- The coastal zone represents a very vast area as it is present in East coast and West coast. Few medicinal plants are Xylocarpus mekongensis, Xylocarpus granatum, Heritiera fomes, Excoecaria agallocha, Avicennia marina, Avicennia alba, Avicennia officinalis, Acanthus bolubilis, Acanthus ilicifolius, Sonneratia caseolaris, Clerodendron inerme, Rhiziphora mucronata, Rhizophora apiculate, Salicornia brachiate, Ipomoea pescaprae, Bruguiera gymnorhiza etc. $(16,23)$.

j. ISLANDS: The biodiversity of Islands have their own flora and fauna different from any other regions. They can also form endemic island diversity; Andaman and Nicobar Islands are one of them. Islands have both inland and littoral vegetation. Till now 2,200 flowering plant species have been reported in this zone(2). Albizia lebbeck, Ailanthus kurzii, Dipterocarpus grandis, Terminalia bialata, Pterocarpus dalbergiodes etc. forms evergreen and deciduous forest which is the part of inland vegetation. Avicennia marina, Nypa fruticans, Calophyllum inophyllum, Terminalia catappa, Manilkaralittoralis etc. forms littoral forest.

Lakshadweep, away from the main land, present in the Bay of Bengal preserves the best evergreen forest of India.

Medicinal plants- Semecarpus kurzii, Strobilanthes andamanensis, Uvaria andamanica, Artabotrys nicobarianus, Calamus andamanicus, Aristolachia tagala, Phyllanthus andamanicus, Glochidion calocarpum, Daemonorops manii, Alstonia kurzii, Dichapetalum gelonioides, Dripetes andamanica etc. are few medicinal plants found in the Andaman and Nicobar islands. (22) 
Polycarpaea spicata, Suriana maritima, Pleurostylia wightii, Colubrina asiatica, Ochrosia oppositifolia, Cordia subcordata, Linaria ramosissima, Pisonia alba, Thuarea involuata, Heroandia ovigera etc. are some known medicinal plants of Lakshadweep island. (17)

\section{BIOGEOGRAPHIC ZONES OF INDIA-}

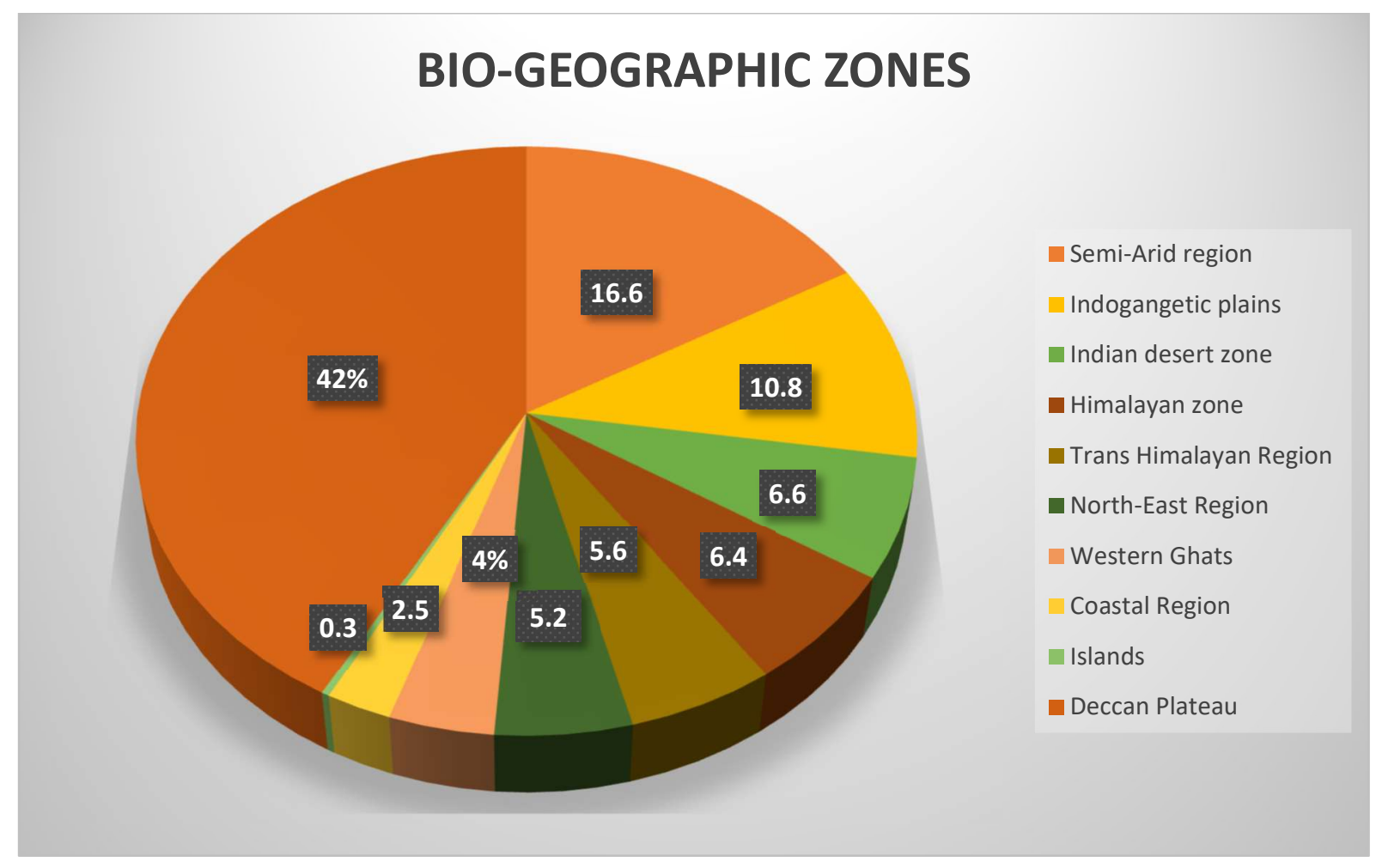

Total species of plants are shown below in the form of Pie Chart.

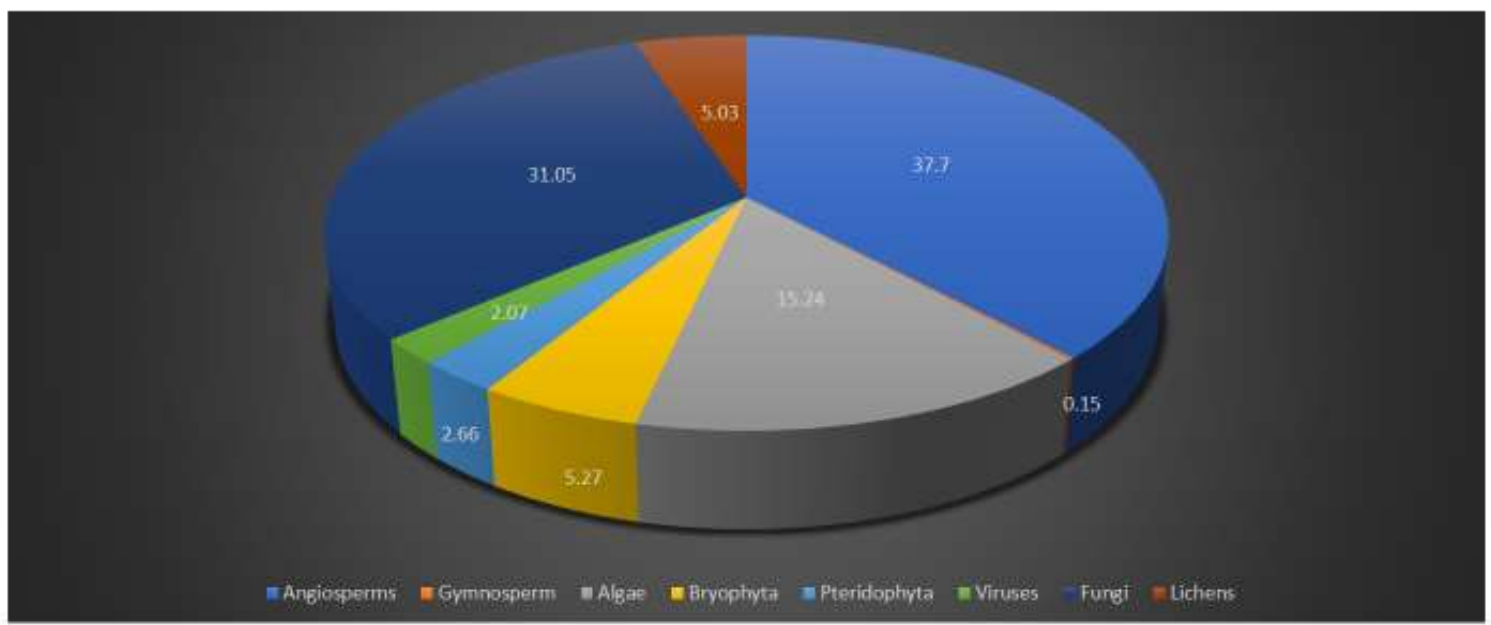




\section{CONCLUSIONS}

In this review paper I tried to put the biogeographic regions of India along with their floral biodiversity and some medicinal plants together. Biodiversity includes both flora and fauna which actually maintain the beauty of the Earth. That's why the conservation is very important as the overexploitation and pollution is degrading the natural habitat of many species day by day, which ultimately caused the extinction of many species and many of them are at the risk of extinction. We need to protect the Earth to protect them. Due to various conditions and diverse range of floras India is blessed to be a Megadiversity country of the World.

About $70 \%$ of the medicinal plants are present in the tropical rainforest of the Eastern and Western Ghats, Himalayas, Aravallis, Chota Nagpur plateau, Sunderbans etc. Kashmir is one of the hotspot regions of the Himalayas but is not completely explored (25). We should explore more without disturbing them so that many new species could come to knowledge. Many medicinal plants are hidden in our deep forests which could be used for the benefits of the society.

\section{REFERENCES}

1. Indian Biodiversity: Past, Present and Future by Stephen A., Renuka Suresh, Livingstone C in 2015 in International Journal of Environment and Natural Sciences, vol. 7, 13-28(2015). ISSN: 2349-3763

2. ENVIS centre of floral diversity 2019 database BSI, Kolkata, West Bengal.

3. 'Floristic diversity of Northeast India and its conservation' by Dr. Krishna Upadhyay, Dr. Hiranjit Choudhury, Dr. Nripemo Odyuo in International environmental economics; Biodiversity of ecology. ISBN: 978-93-5056-152-2

4. 'Diversity of Indian flora' by R R Rao Indian national science academy. B63 no. 3 pp. 127-138(1997)

5. 'High altitude biodiversity of Alps and the Himalayas: ethnobotany, plant distribution and conservation perspective' by Chandra Prakash Kala, Petra Ratajc in Biodiversity conservation (2012) 21:1115-1126. DOI 10.1007/s10531-012-0246-x.

6. 'The floristic diversity of the Western Ghats and its conservation A review' by Nair N C and Daniel P 1986; Proc. Indian Acad. Sci Suppl. Pp. 127-163

7. 'Flora of Indian desert' by M M Bhandari 1978; ed. 2 M.P. Repros, 1990 (Jodhpur: Scientific Publisher).

8. Pandey, R., and C. N. Pandey. "Spatial and temporal variations in floral visitors of a mangrove species-Aegiceras corniculatum (L.) Blanco-in the Marine National Park, Gujarat, India." Int. J. Bot. Res 3.1 (2013): 35-42.

9. 'History, biogeography, biodiversity and bio-prospecting scenario from the Western Ghats' by Giby Kuriokose and Jis Sebastian. South Indian Journal of Biological sciences 2016; 2(2); 292-301. ONLINE ISSN: 2454-4787.

10. 'Floral diversity' by Gautam Kumar Das. Estuarian Morphodynamics of the Sunderbans, 139-157, 2015.

11. 'Biodiversity of Andaman and Nicobar islands' by Maruthamuthu Balakrishnan et al. in 2008.

12. 'Floristic structure, diversity and edaphic attributes of /mangroves of the Andaman Islands', India in 2020 by S. Sreelekshmi et al. Thalassas: A Journal of Marine Sciences 36, 47-60(2020). DOI 10.1007/s41208-020-00191-2.

13. 'Biodiversity profile of India' by A. Balasubramanian in 2017. DOI: 10.13140/RG.2.2.10664.57601.

14. KARIMA, BENOUFELLA-KITOUS, DOUMANDJI SALAHEDDINE, and MEDJDOUB FERROUDJA. "Interest and place of three Vicia faba aphid species in Draâ Ben Khedda (Great Kabylia, Algeria)." International Journal of Agricultural Science and Research (IJASR) 4.6 (2014): 27-36. 
15. 'Semiarid region of India: Vegetation characteristics and threatened plants' by Amit Kotia, Dr. Umesh Kumar Tiwari, Gopal S. Rawat in 2008

16. Medicinal plants of Rajasthan in Indian system of medicine by Yogesh Chandra Tripathi. Ancient Science of life, 15(3): 190212(1996).

17. 'Review of medicinal plants used by local community of Jodhpur District of Thar desert' by Manoj Goyal et al. in International journal of pharmacology. DOI: 10.3923/ijp.2011.333.339.

18. De, L. C., and D. R. Singh. "Natural resources in North East region of India." International Journal of Agricultural Science and Research 7.5 (2017): 51-66.

19. 'Medicinal plants of coastal zone' by Abhijit Mitra in 2020 in Organic and medicinal chemistry International Journal ISSN 2474-7610.

20. 'Few rare and interesting plants occurring in Lakshadweep' by Sivadasan M. J. Econ. Tax. Bot. Vol. 3(1982).

21. Bori, Geetashree, and M. Neog Rupjyoti. "Emerging Trends in Woven Textile Fabrics Designs of Tribal Mising Community in Assam." International Journal of Applied and Natural Sciences (IJANS) 6.5 (2017): 7-14.

22. 'Economic value of Medicinal plants in Indo-Gangetic plain areas of Kanpur: An Urban Environment' by Alpana Tewari and Archana Srivastava. Trends in Biosciences 4(2): 201-204, 2011.

23. 'Genetic diversity and conservation of medicinal plants in Deccan plateau region' in India in Journal of Medicinal plants studies 2017;5(3):27-30. ISSN (E):2320-3862

24. 'Unexploited plants of potential medicinal value from the India Thar desert' by Sher Mohammed et al. Natural Product Radiance Vol 3(2) March-April 2004.

25. 'An introduction to traditional medicines of semi-arid regions' by Santosh Sharma and Ashwini Kumar in International Journal of Life Science and Pharma Research vol 2/ issue 3/Jul-Sept 2012. ISSN 2250-0480

26. 'Medicinal plants used by tribes of Andaman and Nicobar islands: A conservation appraisal' by Dr. M. Punnam Chandar et al. in Indian J. Plant Genet. Resour. 31(2) : 125-133(2018). DOI: 10.5958/0976-1926.2018.00015.3

27. 'Ethnomedicinal studies of Pichavaram mangroves of East coast, Tamil Nadu' by K.C Ravindran et al. in Indian journal of traditional knowledge vol 4(4) Oct. 2005, pp.409-411.

28. 'The Himalayas of India: A treasury of medicinal plants under siege' Biodiversity, 4:3,3-13, DOI: 10.1080/14888386.2003.9712694 by Hemant K. Badola and Stephan Aitken.

29. 'General overview of medicinal plants: A review' by Refaz Ahmad Dar et al. in The Journal of Phytopharmacology 2017;6(6):349-351. ISSN- 2320-480X.

30. Future of endemic flora of biodiversity hotspots in India by Vishwas Sudhir Chitole, Mukund Dev Behera, Partha Sarathi Roy in Plosone journal. DOI: 10.1371/journal.pone.0115264.s002.

31. 'Conservation status of Medicinal Plants in Ladakh: cold arid zone of Trans-Himalayas' by G.Phani Kumar, Raj Kumar and O.P Chaurasia in Journal of Medicinal Plants volume 5(6): 685-694,2011.

32. The number of known plant species in the world and its annual increase by Marteen J.M. Christenhusz and James W. Byng in PHYTOTAXA 261(3):201-217.

33. Medicinal plants of Western Ghats by Suja A. Sahyadri:Western Ghats Biodiversity Information System, IISc, Banglore. 
34. Medicinal plants of North-east region of India: A small review by Mrinmoy Sharma, Biswajit Das in International Journal of Current Pharmaceutical research, Vol 10, Issue 4,11-12. 